Salesian Journal of Humanities and Social Sciences, Vol. X, No. 2 (Dec 2019)

ISSN: 0976-1861 | 10.51818/SJHSS.10.2019.22-47 | Page: 22-47,

Section: Articles

\title{
A Conciliatory Gaze: SNG on MK Gandhi and BR Ambedkar
}

Geroge Thadathil is the Principal of Salesian College, Sonada and Siliguri. He is the author of Vision from the Margin and has edited and co-edited number of books besides contributing to a number of journals and edited volumes. He is the founder Director of Salesian Publications, Salesian Research Centre and Salesian Translation Centre.

The paper is a continuation of the research undertaken nearly 20 years ago motivated by the conviction that in the contemporary socio-political scenario of the country, the vision of Narayana Guru has a contribution to make. Though his name finds a place among others like Jyoti Rao Phule, Periyar and Ambedkar on the one side, and RamaKrishna, Aurobindo, Gandhi and Tagore on the other, a mediation is yet to be effected: a mediation between a dominant vision and a subjugated people within the philosophical history of India. In other words, the disillusionment as regards Gandhi's project for modern India among the Dalits, Adivasis and Women on the one hand, and the circumspection as regards Ambedkar's version of modern India among the upper castes and strata on the other, pose the need for a new path. There could possibly be in SNGM vision an answer to the search for selfhood of a people to re-script the nation. The paper explores the theme by looking at the following: first, the emergence of SNG movement and thought; second the question of religious conversion within socio-cultural specter of Ambedkar-Gandhi; third the contemporary flow of religious wisdom into politics; fourth the opening to the resurgence of religion for humanity that SNG offers.

Keywords: Gandhi-Ambedkar debate, Caste, Conversion, Narayana Guru.

\section{Introduction}

Pursuing, more than returning to, the research undertaken nearly 20 years ago is indeed an occasion to look more squarely at what motivated it then as now. There was then and even now, this conviction that in the contemporary socio-political scenario of the country, the vision of Narayana Guru has a contribution to make. Though his name finds a 
place among others like Jyoti Rao Phule, Periyar and Ambedkar on the one side, and Ramakrishna, Aurobindo, Gandhi and Tagore on the other, a mediation is yet to be effected: a mediation between a dominant vision and a subjugated people within the philosophical history of India. In other words, the disillusionment as regards Gandhi's project for modern India among the Dalits, Adivasis and Women on the one hand, and the circumspection as regards to Ambedkar's version of modern India among the upper castes and strata on the other, pose the need for a new path. There could possibly be in SNGM vision an answer to the search for selfhood of a people to re-script their identity.

Therefore, in this paper I would like to visit the renewed interest in Gandhi-Ambedkar debate triggered in the past decade and attempt to insert Narayana Guru into the constellation so as to expand and focus on the discourse. In doing so I shall limit to their contestation on the issue of conversion within their respective understanding of religion and God for humanity. In the search for potential reconciliation of the irreconcilable positions of Gandhi and Ambedkar possibly lies the future of Indian cultural, civilizational contribution to the ongoing human journey. The notion of Narayana Guru's atma sukham (self-happiness or self-joy or soul-bliss) can be conceived as a purification process of all religious views and in itself being an alternative conceptualization of spiritual wellbeing. The attempt to ground such search for wellbeing individually as well as collectively within the frame of rationality and soulfulness, the inner life force pulsating in the body-mind complex of selfhood is probably the metaphysics that brings them into a political constellation enabling to view the future of humanity better and clearer. This is an attempt to bring the somewhat unknown and hidden views and philosophical position of SNG into dialogue with the more elaborately written and argued positions of Ambedkar and Gandhi.

I will explore the theme by looking at the following: first, the emergence of SNG movement and thought; second, the question of religious conversion within socio-cultural specter of Ambedkar-Gandhi; third, the contemporary flow of religious wisdom into politics; fourth, the opening to the resurgence of religion for humanity that SNG offers. 


\section{4 / Geroge Thadathil}

Salesian Journal of Humanities and Social Sciences, Vol. X, No. 2 (Dec 2019) ISSN: 0976-1861 | 10.51818/SJHSS.10.2019.22-47 | Page: 22-47,

Section: Articles

\section{SNG: The Apostle of Casteless Consciousness}

In this first part, instead of narrating the movement's history, I retrieve snippets from the life and times and sayings of SNG from authors who have collected and used them with differing perspectives. Those who attempt to read the tradition literally and focus on the value he is communicating and also those who critically read the tradition to analyze the origin or sources of his own texts. Secondly, my focus is on Narayana Guru and his ideas as carried forward by his disciples, especially of the gurukula foundation lineage. Thirdly, my own study and reading has been to locate the movement as an offshoot of the community but having wider attractive force and adherents. If the corpus of writings by him and on him are scouted, one can clearly see the two sides of the person of SNG: the soft, passive, philosophically and mystically oriented spiritual persona, and on the other an active, agent of engagement with social and religious structures of the prevailing socio-political context arguing for and demanding action to rectify and modify society - his own community (samudayam), ${ }^{1}$ in the narrow sense as well as in the larger sense of the whole human society.

The following quotes from other authors who have studied Guru, justify the first part of the Guru persona:

When we open our hearts to the suffering of human beings, of other beings, and even the Earth herself, it is easy to become discouraged and sad. Even Narayana Guru himself experienced the pure sorrow that comes to a true lover of life. Once Rabindranath Tagore, the well-known poet, visited Narayana Guru in Kerala. The followers of the Guru arranged a great procession including elephants and music. The Guru had the best carpets of the hermitage spread on the ashram verandah where the visitor would sit. The crowd thronged around to hear what the two leaders would say to each other. When silence finally came, Tagore congratulated the Guru on the great work he was doing for the people. Guru replied with great earnestness, "Neither have we done anything in the past nor is it possible

\footnotetext{
${ }^{1} \mathrm{Cf}$. The distinction made below by Udaya Kumar in his study on the word as used in the original language, Malayalam.
} 
Salesian Journal of Humanities and Social Sciences, Vol. X, No. 2 (Dec 2019) ISSN: 0976-1861 | 10.51818/SJHSS.10.2019.22-47 | Page: 22-47,

Section: Articles

to do anything in the future. Powerlessness fills us with sorrow. ${ }^{2}$

In example after example, from the large scale to the small, Narayana Guru manifested a supremely effective and thoroughly gentle way of life that each individual can practice, in any circumstance. In Scriptures of Mercy (Anukampa Dasakam), the Guru gives beautiful expression to the core of that way of life:

Grace yields blessedness; a heart Love-empty

Disaster spells of every kind.

Darkness as love's effacer and as suffering's core,

Is seed to everything.

Grace, Love, Mercy - all the three -

Stand for one same reality - Life's Star.

"He who loves is he who really lives."

One who loves is one who really lives: these few words - compassionately given to us by Narayana Guru -invite us all to embrace a life of passion and compassion. ${ }^{4}$

On the other hand, in the following quotes from other scholars on Narayana Guru's war on caste, one get's the latter view of the person:

Authors of caste may say that it will prevent unhealthy competition. Those who get all the benefit of the system may say so. Probably their happiness is built on the sufferings of others. Man is not made for castes, for the world or any such thing. All these are for men. If men are degenerating, what is the good of talking about less competition and so forth? Caste degenerates man and so it is not wanted. There is no caste; it is foolishness to think there is." ${ }^{5}$

${ }^{2}$ Quoted in Nancy Yielding, "Passion and Compassion of Narayana Guru," in Philosophy, Vision and Work of Narayana Guru as an Instrument of Egalitarian Social Change, Shimla, IIAS Conference Papers,7-9 June 2011.

${ }^{3}$ Nataraja Guru (translator), Anthology of the Poems of Narayana Guru, (Narayana Gurukula, 1977), 41.

${ }^{4}$ Nancy Yielding, op cit.

${ }^{5}$ T.K. Ravindran, Vaikom Satyagraha and Gandhi, Sri Narayana Institute of Social and Cultural Development, Trichur, 1975, 13. (taken from Nancy Yielding, op.cit). 


\section{6 / Geroge Thadathil}

Salesian Journal of Humanities and Social Sciences, Vol. X, No. 2 (Dec 2019) ISSN: 0976-1861 | 10.51818/SJHSS.10.2019.22-47 | Page: 22-47,

Section: Articles

Narayana Guru had once remarked, "If you consider me an incarnation, tell all the people that the purpose of this incarnation is to annihilate the demon of caste".${ }^{6}$ This declaration clearly reveals the attitude of the Guru towards the issue of caste, an attitude of total negation and disapproval, and a sense of commitment for its annihilation. Being fully aware of the Hindu scriptural injunction on caste, often misinterpreted, its historic development as part of the Hindu religion, and its stifling effect on the development of human potential, his war on caste was based on a very strong philosophical substratum which became the well-spring of rational practical action. ${ }^{7}$

According to him, caste is a state of mind, with a long history. When examined objectively, it dissolves into nothingness. Caste would taste bitter or sweet alternately depending on who is losing or gaining in the process. Caste difference is imaginary, not actual. Caste is Brahmin versus Paraiah dialectics. The false notion of caste has arisen out of the interaction between these two group identities. These two ideas are super-imposed on one reality that is human nature, which is essentially one.

The ultimate objective of the Movement was to achieve integration of the society, realization of the unity of mankind by recognizing the divinity hidden in all, reformation of the society by uprooting evil and inhuman practices and superstitions, emancipation and uplift of the downtrodden spiritually, socially and economically. Abolition (demolition?) of caste, is the prime factor in this great endeavour, as caste was the stumbling block in every aspect, dispiriting the people through petrified slavishness.

On several occasions he had revealed his contempt for the system, and the frustration of his soul in this issue. A casual incident in a train on his way to Madras throws light on his attitude. A young Indian in European dress (some biographers say that he was a Nambudiri) was sitting in the same compartment. He asked the Guru seriously,

\footnotetext{
${ }^{6}$ Sathyabai Sivadas, "Casteism as Redefined by the Guru" in IIAS Conference Papers, 7-9 June 2011.

${ }^{7}$ Ibid.
} 
What is your name?

Narayanan.

Of what caste are you?

What do you think? Guess.

I cannot make out from your appearance

If you cannot know by sight, how can you through hearing?

On hearing a report of this from the Guru at Madras, a young firebrand blurted out that the so-called sacred thread of the twice born should be burnt. The Guru commented:

If there are half a dozen youths of such enthusiasm, the curse of caste can be exorcised in no time. No special proof is required to believe that all human beings belong to the same jati. A dog, on seeing another, recognizes it as one of its own kind. Every animal has this instinct except man. Only he has doubts. He is inferior to beasts. ${ }^{8}$

These words do not humiliate human beings, rather, they are the flames of agony that emanate from his frustration about the miserable state of ignorance that has enveloped mankind. These are glimpses into the life and mission of an individual who spearheaded a movement and a social revolution in Kerala in the late nineteenth and early twentieth century, and its after effects continue to define Kerala society.

The details of the emergence of the movement have already been detailed in my earlier work. Therefore, I do not repeat other than stating that Sri Narayana Guru and his immediate disciples and the lineage continued in the Gurukula Movement have played a significant role in keeping alive the inner dynamics of the Guru Message in critiquing society for its reclamation of true welfare.

\section{The Issue of Conversion, Christianity and Gandhi}

The book on Gandhi by Stanly Jones" has a chapter in it, "Gandhi and the Christian Faith" wherein the focus is Gandhi and his attachment-

${ }^{8}$ Ibid.

${ }^{9}$ Stanley E Jones, Mahatma Gandhi: An Interpretation, (New York: Abingdon Press, 1948). 


\section{8 / Geroge Thadathil}

Salesian Journal of Humanities and Social Sciences, Vol. X, No. 2 (Dec 2019) ISSN: 0976-1861 | 10.51818/SJHSS.10.2019.22-47 | Page: 22-47,

Section: Articles

detachment towards Christianity, and helps to see the differing lens with which Ambedkar and Gandhi views the question of conversion. The 'Christian' spirit in him observed by most of the westerners and Christians who came close to him, and by assertion of his own experiences with the Christian friends he had and the attempts he made to understand Christianity, are what made him desire, and come close to appreciate the vision of the equality that Ambedkar saw as the quintessence of a 'free' and 'democratic' society. The means to achieve it, either by preservation of his ascribed identity 'as Hindu', as seen by Gandhi, or, by the negation of it, 'I shall not die a Hindu,' as asserted by Ambedkar, became the platform of contestation.

The question of conversion can be taken at various levels. Firstly, as alluded in what Felix Wilfred asks: "why is conversion for the sake of spiritual illumination necessarily superior to what is done for the realization of one's survival?" Herein the assumption being that whether be it for spiritual or material motives a person decides to 'convert' (change one's belief or faith or religion) need not discredit the veracity of that choice. Secondly, as Walter Fernandes takes it in the particular context of those communities that decided to change their religion from one to the other as having done it because, 'conversion' is not "an encounter between Hinduism and Christianity but a protest on the part of Dalits against social injustice" ${ }^{10}$ and as having the right to take recourse to actions to redress the injustice or escape the injustice, or challenge the injustice. Thirdly, for Anantha Kumar Giri, Gandhi "looked at Jesus as a Satyagrahi and in his engagement with and challenge to Christianity brought out the different implications of the cross in societies and histories."11 In his reading Gandhi was opposed to conversion to Christianity though "he himself was wavering between Hinduism and Christianity seriously considering conversion to the latter at one time" because his first priority was reform of one's religion and the responsibility revolving around it.

\footnotetext{
${ }^{10}$ Walter Fernandes quoted in Ananta Kumar Giri, "Hindu Engagement with Christianity" in Wilfred (ed), Oxford Handbook of Christianity in Asia, (London: OUP,2014), 401.

${ }^{11}$ Ibid, 395.
} 
Fourthly, as Aishwary Kumar engaging with the Ambedkarian critique of the system of caste and the logic he unveils in the Annihilation of Caste, comments "if there was a central lesson... an irreducible 'principle' that underpinned its formula of 'truly religious act' it was the conviction of Ambedkar that 'the democratization of religion - the duty to make faith accessible to everyone freely and equally - was a people's highest obligation toward itself." 12 He admired Karl Marx who saw religion as alienation, but unlike Marx's views on religion, the above stand is his testament in the possibilities of religion in a democracy. He believes in religion, is significant, just like Stanly Jones' observation that Gandhi did not reject Christianity and Jesus is a great thing. Kumar interprets Gandhian ahimsa as not 'nonviolence' but as non indifference, ${ }^{\prime 13}$ and thus would leave room for the possibility of being committed to a cause as also to a religious faith by choice. In contrast, applying force of any kind to ensure that someone changes his or her life position would be violence and against the principle of ahimsa. Ambedkar was contesting this stand on the part of Gandhi 'of not wanting others to change their life position' as condemning them to their misery, seen as he does from the position of the depressed classes.

The aspiration for equality is at the base of the choice for conversion. Equality is seen differently by both Gandhi and Ambedkar, as shown by Kumar in the two different words - samadarshi and samata: Samadarshi, for Gandhi is the one who is capable of practicing equality being visibly moved to act differently but justly to different persons. It is a matter of principled judgment, the notion of equality is a visible movement towards each from a presence filled equanimity that brings about the ideal of equality. For Ambedkar 'caste is a notion, it is a state of mind'. The destruction of caste does not therefore mean destruction of (visible walls/barriers) physical barriers. It means a more than notional, a moral change. On the other hand, " $[\mathrm{t}]$ rue equality requires autonomy and freedom, a renunciation of

12 Aishwary Kumar, Radical Equality: Ambedkar, Gandhi, and the Risk of Democracy, (California: Stanford University Press, 2015), 40.

${ }^{13}$ Ibid, 45. 


\section{0 / Geroge Thadathil}

Salesian Journal of Humanities and Social Sciences, Vol. X, No. 2 (Dec 2019) ISSN: 0976-1861 | 10.51818/SJHSS.10.2019.22-47 | Page: 22-47,

Section: Articles

measure and limits that politics imposes on it" $^{\prime \prime}{ }^{14}$ and can be attained only in a state of samata - by equal citizens. The faith in the possibility of such a state of affairs is the highest responsibility and thus 'the faith' of the citizen in the world. Conversion to such a faith therefore is quintessential to being a good citizen.

In understanding the objection raised by Gandhi to conversion, the very understanding of the concept within western religio-cultural thought, and the conflation that Gandhi does of interpreting it from his own religio-cultural frame and for the western audience, or those supposedly preaching Christianity for the welfare of Indians, needs unpacking is the argument that Sarah Claerhout makes in her study on Gandhi and conversion. ${ }^{15}$ In Gandhi's various statements about Conversion she sees three possible assertions: first, that it is possible and justifiable if it is towards a better moral wellbeing of the person concerned, though, for Indians in becoming Christians the possibility of becoming morally better is not assured by Gandhi, and not only, he sees such endeavours as divisive of the community and the tradition into which one has been born; secondly, every individual has the responsibility to reform and improve, purify the faith of his or her own tradition, and it is in this sense that the act of conversion touches on the issue of undoing 'untouchability' and it is about this act of reform and its possibility within the 'faith frame' and not by going outside or deserting it, is where Gandhi positions himself. Whereas, for Ambedkar, if the purification of the tradition, the given religion, is not feasible, viable, and not achieved, as seen even in the commitment of Gandhi towards it, what else is the option than to convert, or in other words, than to conceive of radical step of stepping out? Gandhi sees Hinduism perishing if this conversion is not willingly undertaken by the caste Hindus, and Ambedkar sees the demise of Hinduism in its present form of 'discrimination on the basis of birth' as the only way forward for the Indian society to become modern; the third

${ }^{14}$ Ibid, 47. He calls caste 'a non violent art of physical and cognitive enslavement' perpetrated over millions.

${ }^{15}$ Sarah Claerhout, "Gandhi, Conversion and Equality of Religions: More Experiments with Truth", Numen, 61(2014): 53-82. 
meaning of conversion for him is in attempting to bring someone else to a new truth commitment through 'preaching or proclamation', and this is not possible, as he sees, because truth is to be lived and morally made binding in one's life, and life becomes the 'preacher' or medium of proclamation. It is in this sense too that Ambedkar, and Roy after him, is trying to expose the flaw in Gandhi, his lack of sincerity, as not having lived the truth of 'equality' that he purportedly avowed to do, ever since his confrontation with Ambedkar in the Round Table Conference and at the Poona Pact. ${ }^{16}$

Shane Gannon, taking up the studies on Conversion of Ambedkar by Gauri, Rodrigues, Susantha Goonatilake and others, applies a hermeneutic of conversion to read them from the Lacanian point de capiton (also known as nodal point or quilting point) or 'thematic site' (as introduced by Anna Klosowska) wherein there is the visible pointing towards the invisible meaning between the signifieds in the symbolic order. She uses this scheme to identify the colonial framework of thought hidden behind the very critique of colonial knowledge by Gauri and Rodrigues, and in order to do so refers to the repeated association with Gandhi and his view of Hinduism being pitted against Ambedkar and his Buddhist turn as a modernist turn, and thereby privileging the West over East and as reinscribing the Saidian Orientalist frame of inferiority of the east/traditional against the superiority of west/modern. It is in this case, reversely deployed as the non-western academics mentioned above, are the ones taking on non-western protagonists like Gandhi and Ambedkar.

Gannon shows how invariably in every commentary on Ambedkar's decision to convert, whether it is political, social, or personal, there is a comparison with the stand of Gandhi. Further this thematic of interpreting Ambedkar's choice of Buddhism against the Gandhian reformed version of Hinduism as a choice for the modern in its democratic ideals of liberty, equality and fraternity is shown as a choice against the retrieval

${ }^{16}$ Cf. George Thadathil, "Reading Gandhi in Ambedkar's Shoes: Reclaiming Democracy," in Johnson Puthenpurackal (ed.), Enhancing Our Home: Re-claiming and Re-reading the Gandhian Thought, (Bangalore: Asian Trading Corporation-ACPI Festschrift, 2016), 193214. 


\section{2 / Geroge Thadathil}

Salesian Journal of Humanities and Social Sciences, Vol. X, No. 2 (Dec 2019) ISSN: 0976-1861 | 10.51818/SJHSS.10.2019.22-47 | Page: 22-47,

Section: Articles

of the past with its caste hierarchy albeit only in new shades within the Gandhian conservative vision. Though her effort is to show how colonial thinking is underlying this attempt to escape the colonial discourse using Lacanian structuralism, our intent is twofold: first, though the western theoretical inspiration lay behind his critique of caste and its pitfalls, that alone is not the source of his critique; secondly, that behind both Gandhi and Ambedkar's reading of tradition as well as its critique there is an experiential content in the knowledge construction over and above what is available to a monocultural, monolingual reader or interpreter, and this latter component is what makes most western-author/reader's critique of Gandhi-Ambedkar debate though compelling in argumentation, fall short of grasping the total picture. The crux of the debate as we have hinted earlier is in the Gandhian rejection of the Ambedkarian possibility of conversion and vice versa. Here the ascribed identity as non-reversible, as for Gandhi, does not hold the water against the Ambedkarian understanding of religious identity as the most fundamental and subscribed to of all identities.

This claim needs a rider in that, it is the western modernity as understood and appreciated by the east/Indian. Secondly in the above assertion of Ambedkar being seen purely making a western modernity critique, the point of his experiential understanding of what is wrong with the Indian traditional (casteist world) and this understanding underlying his critique is not acknowledged. Therefore, his critique is both western modern and indigenous/Indian modern in as much as he is making it not only in terms of ideological frames gained from the theories of his mentor, Dewey, but also from his own experiential critique of what is inadequate and wrong in the Indian-traditional. ${ }^{17}$ The latter angle of perception is missed in this critique. Having scouted some of the more recent studies on the Gandh-Ambedkar debate on the issue of conversion, bringing the duo into conflation with SNG is the forthcoming task.

${ }^{17}$ Cf. The argument made by Gopal Guru, "From Bhakti to Buddhism: The Mahars of Maharashtra" in the Metaphysics and Politics, Cochin Conference 2013 of the Backwaters Collective. It substantiates this reading. 


\section{On Caste \& Conversion: SNG vis-a-vis Gandhi-Ambedkar}

As seen in the above quote, at the end of section one, on "Jati" he inverts the logic of Gandhi, who challenged by Ambedkar says no to Jati and yes to "varna" as an ideal system of division of labour. Instead SNG asks, why not reduce everyone to the same caste, understood in its primordial, biological sense to which all other nuances of it are at the end of the day, reverted to, whether one accepts it or not. If so, just as dogs and cows recognize each other as belonging to one kind (inam/jati/species) why not educate or deconstruct the falsely added notions of 'difference' is what he poses. Underlying it is therefore, where and how does the differentiation originate? Ambedkar in his analysis, takes it back to the scriptural sanctioning on the strength of which one community/caste group gets the pre-eminence to decide on the fate of the others, as he refers to in the case of Shivaji being disclaimed by the Brahmins and having had to import a Brahmin from Benares to sanction his Kingly status. In other words, just as Kingship and Monarchy have been done away with in order to introduce democracy, the undoing of the brahminic ideological stranglehold on social mores and practices alone can redeem Hindu society. What we then have is an alliance of the frame of reference of Ambedkar and SNG against the forces that want to retain the traditional mould, as represented in the voice and partial concerns of Gandhi.

Even here, though a detailed elaboration of the debate has already been dealt with in another recent article, the intent of the discussion is to profile the three significant voices on the issue of Caste and Conversion which is being debated to date in the Indian public sphere. A good place to start would be the first and only encounter between MK Gandhi and Narayana Guru when the latter came to Travancore in connection with the Vaikkom Sathyagraha, and visited the Guru on $12^{\text {th }}$ March, 1925 at Sivagiri, stayed overnight and addressed the Public on the morning of 13th March 1925. By then Gandhi had established his credentials as the voice of Indian nationalism and was onto strengthen this hold by garnering support from various quarters - regional and linguistic and caste diversities that characterized the Indian scene. 


\section{4 / Geroge Thadathil}

Salesian Journal of Humanities and Social Sciences, Vol. X, No. 2 (Dec 2019) ISSN: 0976-1861 | 10.51818/SJHSS.10.2019.22-47 | Page: 22-47,

Section: Articles

It could be averred that he was a supporter of caste system from the fact that his Hind Swaraj, the manifesto for Indian Liberation had no mention of the problem of caste and untouchability plaguing the country. He seemed to have moved on to a position of accepting caste if untouchability was done away with and therefore initiates plans for the same. Their encounter and his visit to Kerala, probably had something to do in this change of position on the part of Gandhi. He pointed to a mango tree in the courtyard and tried to justify the caste system by expressing that, as the difference in the size and shapes of the leaves is a natural phenomenon, difference between human beings is also natural. But the Guru negated this argument with the fact that though the leaves are different in size and shape, their juice tastes the same, similarly all human beings are similar in essence. Gandhi makes no mention of the logic in this argument in his speech at Varkala in response to the SNDP Yogam's memorandum submitted to him, but uses the tree and leaves to claim his point of differences and accommodation of differences as a people. He rides on two boats very dexterously, trying to appease the listeners in their eagerness to gain equality of access to public roads and at the same time lulls their awakening consciousness by harping on the need for patience and moral character by being able to live with the orthodox and their resistances till they come to change the point of view and accept the claims placed by the weaker sections.

On this incident Joseph Lelyveld comments that the view outside Kerala and inside are different, one as giving the general acceptance of the Gandhian position on satyagraha by its practitioners in Kerala, and the other, that of those within Kerala who knew better of the ambivalence Gandhi showed towards the cause and thereby reinscribing his own bias towards perpetuation of caste barriers than its eradication, as desired by the satyagrahis at Vaikom. He also notes that the Kerala Guru followers interpret the encounter to the extent of Gandhi having learned from the Guru while in actuality he came out the same as he went in to meet the Guru, ${ }^{18}$ as substantiated by the text of the speech he delivered the

${ }^{18}$ Joseph Lelyveld, Great Soul: Mahatma Gandhi and his Struggle with India, (New York: Vintage Books, 2011), 192-194. 
following morning which is available from the police sources. ${ }^{19}$

In the light of difference of approach to the issue of 'caste' the question we keep exploring is whether Narayana Guru was for or against utilizing the religious conversion plank as a means to get the community's rights redressed. In this regard, there seems to be the possibility of a double interpretation of Guru, depending on who and for what purpose one is attempting to read into his statements and assertions in different contexts. As for contradictory statements, whether or not the overriding stand on premise and principles by which a person lived and have left testaments to that effect should precede over contextual exceptional statements. It is this sort of an exercise Udaya Kumar does in his study of the usage of the word 'community' (samudayam) and religion (matam) by Narayana guru and takes the position that he did not endorse 'conversion' as an option for caste eradication. ${ }^{20}$

Sree Narayanan also distinguished the concept of matam from that of samudāyam. It is wrong to subordinate matters of the community (samudāyam) to religion (matam) or religious matters to the community. There should be no connection between community affairs and religion. Religion is a matter of the mind. These views also meant that Sree Narayanan did not endorse conversion as a strategy in anti-caste struggles. In the early 1920s, Ezhava leaders like C. Krishnan, C. V. Kunjuraman, and Sahodaran Ayyappan argued that Ezhavas should leave the Hindu fold in order to free themselves from the disadvantages of the caste system. Narayana Guru clarified his position on conversion in two conversations with C. V. Kunjuraman and with Sahodaran Ayyappan. In these exchanges Sree Narayanan used the word samudayyam in another sense. 'Religion (matam) has two sides: one internal and the other external,' he says, 'Which of these sides would you like to see changed?' He continues: 'If the desire

19 Selected Documents on Vaikom Satyagraha, The Speech delivered by MK Gandhi at Varkalai Mutt (madom) at 7.05 am on 13 March 1925. Reported by the Police Department and submitted to the Chief Secretary of Government of India.

${ }^{20}$ Cf. Udaya Kumar, "Differences in Conversation: Ethics, History and the Community in Sree Narayana Guru and P. Palpu," submitted at the Metaphysics and Politics Conference, Backwaters Collective Varkala, 28-30 July 2012, wherein he quotes from Vivekódayam, vol. 1, no. 2 (1905), p. 41, a magazine of the SNDP Yogam which printed certain statements attributed to Sri Narayana Guru. 


\section{6 / Geroge Thadathil}

Salesian Journal of Humanities and Social Sciences, Vol. X, No. 2 (Dec 2019) ISSN: 0976-1861 | 10.51818/SJHSS.10.2019.22-47 | Page: 22-47,

Section: Articles

is for change in the external aspect, it is not really religious conversion (mataparivarttanam), but change in community (samudāyaparivarttanam). As for internal religion (abhyantara matam, also meaning inner belief, inner opinion), it is subject to constant and gradual change in all thoughtful people.'.....21

I have in an earlier work attempted to interpret the jati (caste) word used by Sri Narayana Guru as to mean 'community' (samudayam). ${ }^{22}$ In my reading of this Malayalam word it gives the opening to both a restricted understanding as well as a larger and broader understanding: it could, for instance, refer to a community in the localised geographical sense as to mean the samudayam of a desam or of a nadu; as also to mean the conglomeration of all people. Narayana Guru in utilizing the word samudayam is opening up to the universalisation of the notion of community, as Udaya too hints at the reference Narayana Guru and Dr Palpu makes to the notion of Ezhava as referring to those who hail from Ceylon, and therefore as needing not the restricted understanding of a jati/caste but as the broader understanding of the 'only jati there can be' that of the one samudayam. In the same vein, matam too as shown by Udaya as being argued by Narayana Guru is a conglomeration of all opinions, and every opinion has a space in the 'oru matam' /one religion he is speaking of and wanting people to rise up to appropriate.

In order to return to the question of conversion vis-a-vis Ambedkar's stand and that of Gandhi, in attempting to position Sri Narayana Guru, I want once again to go back to an earlier paper by Udaya Kumar. In his comparison and contrast of the two personalities of Sri Narayanan and Dr. P. Palpu he places Guru in the camp of Gandhi, establishing the non-necessity of conversion to overcome caste disabilities, and quotes the statements of Guru from Vivekodayam (1914-15) issues to hint at the restricted sense of community (samudayam) to which he subscribed as also to the stand against conversion taken in the particular instances of people seeking re-affiliation having converted. In his well orchestrated paper,

${ }^{21}$ Ibid.

${ }^{22}$ George Thadathil, Guru Vision: The Study of SNGM in the Literature of NCY, (BangaloreSonada: ATC \& Salesian College Publication, 2007), 101-3. 
the study on samudayam/community, caste as more than body marker and matham as more than opinion referring to the broader community of manushya samudayam, and affinity to that sense of the progressive religion which is a summation of all religions'; and, in his recovery of the Buddhist empire and its linkages with the Izhava community that Dr Palpu tried to emphasize in his various speeches, I am in agreement with Udaya. However, on the question of conversion and the religion issue, I would differ from the interpretation he offers, going by the broader angle of Guru's overall stand on the issue. I would like to place him in the camp of Ambedkar and argue that taking a step along the Ambedkarian critique is the better path to understand his own position, as a socio-political as well as religio-cultural theoretician. I shall use his most prominent and uniquely his own conceptualizations in order to argue my case.

The two most prominent verses of SNG are: Matam etayalum manushyan nannayal mati; oru jati oru matam or daivam manushanu (whatever be the religion man/woman should become better; one God, one religion, one caste for humankind). When one says 'whatever be the religion' it spontaneously implies no preference for any one religion; it also implies that one may move from where one is to where one would like to be. Or in the reverse, it could also refer, that wherever you are is good enough to become better. The possibility of becoming better - as understood as equal to any other - is denied, by the caste order, is what Ambedkar highlights. SNG is stating that 'becoming better' if it calls for 'changing ones belief', one ought to do so. In either way what is the best state of mind? Where does one find the flowering and fulfillment of the goal of being human seen as realized/realizable - and there is the 'one religion'. One may say, this does no good, as it can take us back to where we began, with each follower of each religion claiming his or her path as that 'one true path/ religion' to make oneself and everyone else better.

At this point we need to restate the bone of contention between Ambedkar and Gandhi. For Gandhi, one cannot conceive of changing one's religion, because it is an ascribed identity, an identity one is born into and cannot escape from accepting its premises and implications by status 


\section{8 / Geroge Thadathil}

Salesian Journal of Humanities and Social Sciences, Vol. X, No. 2 (Dec 2019) ISSN: 0976-1861 | 10.51818/SJHSS.10.2019.22-47 | Page: 22-47,

Section: Articles

of being positioned where one is born - just like the language, the race/ caste and the location, one is also born into a religion. For Ambedkar, the most fundamental of all human rights, by dint of being a human being, is the right to choose; the most inalienable and foundational of all choices, is the choice; that is, the ability and the necessity to choose, appropriate one's religion. Therefore his assertion, 'I was born a Hindu but I won't Die a Hindu'; or that of his argumentation building upto that foundational choice, by clarifying the necessity of The annihilation of Caste, through his critique of Who were the Sudras? and The Origin of Caste System in India.

It would seem, therefore, that the position of Gandhi is constricted, seen from the Ambedkarian viewpoint: what constricts it is the inevitability of religion being tradition bound, accepted just because of the weight of tradition and the inability on the part of the individual to critique and think through the premises and the implications of one's derived 'religion', religious beliefs. On the other hand can we equally say that there is something lacking in Ambedkar's position: probably, theoretically, the need to receive or appropriate a religious belief and practice after having understood and accepted it freely as a personal choice, one cannot contest; but may be, the difficulty that could arise as to one not having the time and the resources to critically analyze and view each of the available religions, before coming to the best one can have, or that of not being in a position to found, or, follow a path on finding all of what one sees around oneself as being inadequate, there could be a problem of limit. Besides, given the contingencies of culture and the rubrics of the weight of tradition and the societal compulsions, one may subscribe to one or the other without being fully drawn into it as a personal choice, but rather attempting to understand and live it ever better. Both these situations, does not diminish the argument of Ambedkar that having been born into Hinduism and seen its flaws in the outright discrimination of the community(caste) into which he was born, he has arrived on close scrutiny and detailed analysis at the conclusion that he would not die a Hindu (implying therefore a conversion). 
Even if one were to give the benefit of the doubt and grant that both Gandhi and SNG agree on the issue of the non-necessity of conversion - seen from their position of agreement that one need not change one's religion in order to become better - gives the adherent to any religion a free starting point. It could also be noted for the sake of the argument that 'agreeing that one need not change ones religion does not mean that one may not change one's religion. However, the condition that one should become better and in this process also attempt to make the religion better is an injunction inbuilt into their position. Coming to Ambedkar's view, there is the right to change one's religion - if, as it is practiced - is not in keeping with the notion of freedom, justice and equality. Therefore, the responsibility to change it and change from it leads him to attempt to reframe a religious basis for India that challenges and replaces the inegalitarian assumption of the caste premises inbuilt into the Hinduism he was born into and saw practiced all through his life. We have to ask how do we mitigate this commitment with that of 'having to become better' or being called to 'become better' whatever be one's religion? Applying this conditionality/premise to Ambedkar himself, he could be seen as attempting to follow the very injunction in trying to revive and recreate out of the old a new religion. A religion that does not sanction discrimination by birth and does not sanction and necessitate the professional continuity across the generations. In this attempt he arrives at Buddhism and leaves an incomplete task of tracing the history of revolution and counter revolution as dealt with in the 'essay on Gita' as Aishwary Kumar reminds in his piece "Ambedkar's Inheritances." 23

SNG's atmasukham is an exposition of his atmavidya, his mode of reinterpreting a tradition for modern man and modern times. Therefore, one way to see the relation between SNG and Ambedkar, is to see in SNG the culmination of the rewriting of a new religious basis for India that Ambedkar wanted accomplished. Had he come across the literature of SNG and read his works, probably he would have had an answer to his

\footnotetext{
${ }^{23}$ Aishwary Kumar. "Ambedkar's Inheritances," in Faisal Devji and Shruti Kapila (eds.), Political Thought in Action: The Bhagavad Gita and Modern India, (Cambridge: Cambridge University Press, 2013).
} 


\section{0 / Geroge Thadathil}

Salesian Journal of Humanities and Social Sciences, Vol. X, No. 2 (Dec 2019) ISSN: 0976-1861 | 10.51818/SJHSS.10.2019.22-47 | Page: 22-47,

Section: Articles

vexed mind. The explication of 'atmasukham' calls for an understanding of Atmopadesasatakam which was earlier named as atmabodham and can mean 'instructions to the self' or 'advice/instruction on the doctrine of self'. Both meanings are legitimate from the title. The instruction aspect is evident in the reference in each stanza to practice - 'may be uttered,' 'may be remembered', 'may be practiced'! It can be seen as enunciated by the Guru or the sishya: in other words, the subject who gives the advice can also be the subject who practices the instruction. There is an element of performativity: a set of actions performed by the self, or, instructed and observed as effecting transformation. It is this transformative dimension that takes us to the 'metaphysics of politics' and vice versa.

\section{The Politics of Religious Wisdom (Metaphysics)}

Is the above ideal, a simplistic, wishful, almost inspired mystical vision of a sage or does it have the teeth to overcome hardcore problems of multireligious societies and communities the world has actually come to be?

In order to answer the above question and also to take forward the question of conversion thereby, I want to reinterpret matham as to mean faith, the most fundamental opinion, self-aware-self-declaration a person can make. Faith is gifted to the human being without any colouring or coding; faith is pure possibility. Faith is the human condition of being born and having to die. It is this dire existential flow and necessity that is being acknowledged without 'conditionalities', clauses, insertions and interpolations - all of which are games of the human mind as a collective effort to group and regroup. It is a consequence of the search for comfort and consolation, providing a feeling of security. A security amidst 'so called perceived strangers' that comes from the trumped up knowledge that one is from one country or the other, one race or the other, one language group or the other, one region in the world or the other, one religious sect/group or the other, one gender or the other. It comforts especially, when one has been through racial discrimination, religious discrimination, caste discrimination, linguistic discrimination, political discrimination, gender discrimination. Besides, there is the prevailing 
notion of politically asserting one's voice and gaining one's rights, precisely by organizing around these identities.

The desire to belong to the human family in its entirety gets bifurcated and actualized in smaller dissected bits of region, country, languages, ethnicities, sects and religions. The responsiveness to the human contact, the warmth of human affection and the possibility of connecting emotionally and spiritually with one another given the spaciousness and the closeness it brings is something that needs no 'restriction', where it not for the linguistic inability to connect or the geographical distances and hurdles that prevent, or the economic and political barricades that are created purposively. This possibility of a 'one world citizenship' as argued for by Gary Davis ${ }^{24}$ and endorsed as the very actualization of the vision of Sri Narayana Guru, by Nataraja Guru, is where the applicability of the vision and its pragmatics can begin to operate as a counter logic and counter theory to the world's problems. What Narayana Guru tradition and the SNGM provides is the theoretical underpinnings of such a world vision: oru jati, oru matam, oru daivam manushyanu..$^{25}$

The unalloyed state of being is the state of bliss, of ananda, of atmasukham. From being attained in flashes, if succeeded to be retained for prolonged

\footnotetext{
${ }^{24}$ Sol Gareth "Garry" Davis (1921-2013) was an international peace activist who created the World Passport, a fantasy travel document based on his interpretation of Article 13, Universal Declaration of Human Rights and on the concept of world citizenship. Author of My Country is the World (1962) and Passport to Freedom (1992) and other works is the founder of the World Service Authority. For more information Cf. https://oneworld. network > world-citizenship; https://www.worldservice.org/gov.html

25 The 'one caste, one religion, one God, for Mankind", the Kundalini Pattu are seen as having parallels in the Tirumantiram of Tirumular. cfr Udayakumar, Self, Body and Inner Sense: Some Reflections on Sri Narayana Guru and Kumaran Asan, in Studies in History, 13(1997). Sree Narayanan argued that there was no "Hindu" religion: what we called Hindu matam was but a collection of various religions such as Sankhya, Advaita, or Mimamsaka matam. If Hindu religion is presumed to be one in spite of such substantial differences, could one not overcome the seeming diversity and conflict among various religions in the world by bringing them all under a common name, "One religion" (Ekkamatam)? This is an important sense in which the phrase "one religion" in Guru's motto, "One caste, one religion, one God for man" may need to be read. (cited from Udaya Kumar, Varkala Conference Paper, 2012 op cit.)
} 


\section{2 / Geroge Thadathil}

Salesian Journal of Humanities and Social Sciences, Vol. X, No. 2 (Dec 2019)

ISSN: 0976-1861 | 10.51818/SJHSS.10.2019.22-47 | Page: 22-47,

Section: Articles

duration, and if accomplished as the state from which one consistently acts, then it is equivalent to being in state of grace, state of pure consciousness. In just "being" the energy of being thrusts forward in the direction it is to go. Therefore, what the Guru propagates is a mode of living that captures the essence of life-flow, and without undue obstruction, or earnestness in rectifying the state of affairs, an action which arises from inaction surges forward in the power and thrust of being.

In SNG the possibility of conversion is the quintessence of originality and flowering of fullness of personhood. It is political and spiritual. Political, like that of Ambedkar, and spiritual, as hinted at by Gandhi. The liberation from the tentacles of tradition to which Gandhi was frighteningly subservient and non-radical in the sense of being politically aggressive as to be progressive like Ambedkar. But conversion is a possibility, it is a necessity, it is a mode of appropriating the quintessence of 'freedom', bliss, atma sukham.' Conversion is feared and reviled by Gandhi not because he does not see the plight of those excluded from the hindufold and humiliated in not being granted an equal status as demanded by Ambedkar, but rather because he does not want to liquidate Hinduism (Hindu dharma) and instead wants to retain its hold on society and keep it as an alternative to Christianity and Islam. If this anti-Christian and antiMuslim tenor is the operating premise for not encouraging conversion and bringing forth traditional arguments in favour of ascribed religious identity, what places SNG above Gandhi and as a Guru (despite the attempt by Gandhi to score a point over SNG and to downsize him and place his supposedly superior conception foisted on his listeners, $)^{26}$ it is the fact that the position of religious identity vis-a-vis human search for happiness and wellbeing is a much more thought out and liberated stand on the part of SNG as it comes from a point of no animosity and no privileged position granted to any - neither the indigenous, nor the major religions, nor the Hindu. It is worth noting that SNG is to have stated that the Hindus have no right to claim freedom from the British when for centuries it has held others, the lower castes, under domination. ${ }^{27}$

\footnotetext{
${ }^{26} \mathrm{Cf}$. The police record of Gandhi's speech at Varkala in 1925, as noted earlier.

${ }^{27}$ Cf. G Thadathil, Vision From the Margin, 202.
} 
The outcome of Gandhi's question and the answer, as if he is eliciting it from SNG, seems to be in the direction of wanting confirmation from SNG as to his own position of there having to be no need for a Hindu or anyone to convert for salvation. Ambedkar's influence on him can be gauged indirectly through all those who among Ambedkar's admirers and those desperate with not making due political mileage, given the caste mentality ridden authorities, ${ }^{28}$ demanding that Ezhavas should follow his lead and convert. SNG's position was categorically not against conversion, as we showed going by his own ideological stand. Even in the case of young Nitya, who lived in the ashram with Gandhi for a while was put off by the subtly coercive tendencies and the prevarication before power and authority and the obnoxious title he chose for the oppressed classes 'harijan' that he decides to dissociate himself from Gandhi and returns to SNG's camp. ${ }^{29}$

Gandhi's fear of Hinduism being overridden by the Islamic and Western Christian forces is being played out in the anti-minority diatribe and violent flare ups ranging from the ideological warfare to the street violence orchestrated by agents who not are hard to be pinned down. The clash of civilizations approach to history as series of culture wars being perpetrated again and again as in the Crusades, in the reformation, in the Spanish wars or in the confrontation of colonial invasion of Americas or in the Chinese invasion of Tibet, or the wiping out of Buddhism from India, or in more contemporary global events targeting terrorism and fundamentalism, offers an explanation that might legitimize its repetition. There is, however, an alternative interpretation and visualizing of the possible future of humanity beginning with what SNG's mystical experience and that of many others. The choice of being with the other and for the other with no fear of the other.

\footnotetext{
${ }^{28}$ Nairs and Namboothris and Kings/Queens who followed their dictates/ sensibilities more than the weaker sections.

${ }^{29}$ Cf. Scott Teitsworth (ed.), Love and Blessings:The Biography of Nitya Chaitanya Yati (second edition): "Moreover, I hated the word "Harijan" that Gandhi had coined as an alternative to "untouchable." Harijan means "son of God," but in practice the pretentious upper caste Hindu makes it sound like "son of a bitch."
} 


\section{4 / Geroge Thadathil}

Salesian Journal of Humanities and Social Sciences, Vol. X, No. 2 (Dec 2019) ISSN: 0976-1861 | 10.51818/SJHSS.10.2019.22-47 | Page: 22-47,

Section: Articles

Narayana Guru's negotiations or syncretic assimilations are visible at all levels making him a true advaitin, a non-dualist as we have argued elsewhere. ${ }^{30}$ He refers to 'Arivu' as Brahman, uses unconventional idols/ representations for God such as mirror, lamps, alphabets, and action oriented texts as in Siddha tradition. The notion of arivu and its equation to Brahman has a saiva siddhanta and siddha tradition origins: arivu (knowledge), ahantha (ego-centric), anthakalangal (inner-voices) - body as the shadow of the soul. The non-duality characteristic of him is not only in his theoretical expositions but in the balance he maintained between the transformation effective contextual engagements and the theoretical expositions. The discourses being made out as the central aspect with the intention to create a literary corpus can thus disfigure or erase a significant part of his astute engagements.

History shows that caste considerations reappear in texts after texts accommodating and defanging the attempts to equalize society attempted, be it by Buddha, Asoka, Kabir, the Bakhti saints, Siddhas or the most recent apostles like Phule, Periyar, Ambedkar and SNG. This incorporation or assimilation process needs resistance. Partly because of the complexity of the process itself. SNG and his views on female body, Ambedkar and his views on Tribals, Gandhi and his patriarchy all go for showing how the status quo makes a comeback. SNG himself saw the probability of him being appropriated by the caste and religion bound tradition, and therefore, in 1916, he clarified through a declaration that he did not belong to any caste or religion and that his founding of temples did not entail his belonging to Hindu religion. ${ }^{31}$ He was concerned with the progress of the human soul towards spiritual happiness. For him religion is a matter of the mind. He engaged himself in both religious transformation and social transformation (mathaparivarthanam and samudaya parivarthanam). In this conception the Ezhava is a society in the human society and lokam is for him the world society as experienced by the individual. The way one is, so, is one's world. Each state in the universe is firmly rooted in our inner experience of that state. It is not important to look at the ${ }^{30} \mathrm{G}$ Thadathil, Vision from the Margin, 213-5.

${ }^{31}$ cfr Uday Kumar, op.cit., 259, Downloaded from sih.sagepub.com at PRINCETON UNIV LIBRARY on March 16, 2016. 
external because it is a reflected image of the state of our inner sense anthakarana. ${ }^{32}$

\section{Conclusion}

The ideological frame within which cultural studies are moving onward is in the direction of restructuring the cultural-civilization legacy of India. This cannot beattempted as a simple return to the past but as an overcoming of the modern civilizational thrust that has come its way in the past 300 years and is ongoing. The engagement with modernity undertaken by the Indian cultural intelligentsia while condemning the objectification and subjectivization of the colonized done by the imperialistic ideologies does acknowledge its service in bringing modernity to India. While availing of the modernity and its benefits especially in an increasingly globalizing world there is a simultaneous attempt to restrict the impact of this modernity within India, as to resuscitate the old and preserve the pristine past and its legacies. This is also accompanied by the efforts to maintain the tastes and technologies of the West and its superiority - through money, and ideological warfare than (yet) through technological lead or weaponry. The latter aspiration of dominance too are not far behind. It is this contestation for hegemony that characterizes civilizational forces - be it Judeo-Christian, Chinese-Confucian, Islamic, or Indian-Hindu.

It is amidst these contesting visions of supremacy at the global level that a spontaneous merger of these various visions themselves as the true heritage of humanity and its potential future that is being unveiled by SNG. It is not a programmatic action in the sense of occupying someone else's space or supremacy or dominance, but, as Nataraja Guru used to say, 'a matter of understanding' the true nature of the human heritage and the path to that world of wellbeing-for-all in its truest sense. Atmopadesasatakam is a perspectival lens, to see the world through, irrespective of the layers of opaqueness that surrounds the clarity of vision underlying it. It divests the layers of codings and colourings to see humanity struggling to be born.

${ }^{32}$ cf. NK Damodran, Kumaran Asante Lekhanangal, 1982, vol2, p.137 quoted in Udaya Kumar, op.cit., p.268. (Downloaded from sih.sagepub.com at PRINCETON UNIV LIBRARY on March 16, 2016). 


\section{6 / Geroge Thadathil}

Salesian Journal of Humanities and Social Sciences, Vol. X, No. 2 (Dec 2019) ISSN: 0976-1861 | 10.51818/SJHSS.10.2019.22-47 | Page: 22-47,

Section: Articles

Guru parampara is a carrier of civilizational legacy. This legacy consists in the indigenous genius to let free people in each generation from the contradicting and at times debilitating strangleholds of tradition and blind beliefs which probably in any earlier generation might have been liberating as a legitimate expression of creative aspirations. Seen from this perspective of streamlining and modulating the 'rectitude' of the civilizational/cultural flow, the contributions of SNG can be seen in the way he offers another hermeneutic key to interpret the world.

The significance of his apparently simplistic but profound assertions are to be seen as a spring sourcing from within a cultural sedimentation of over 1500 years of four religions co-living in and around CochinTravancore and over 2 millennia of three religions - this cultural narrative of co-living without combativeness but may be superiority claims by each $^{33}$ (as Ashis Nandy has shown) is what is being challenged by SNG. It does not matter your path, provided you keep walking (whatever be the religion the human person should become better). The second significance to his dictum and its hermeneutic value arises from the contemporary combative stand that religions have taken towards one another. While the truth of the religion ought to bring them together to journey together, the non-essentials of religion - given the political and economic expedience - take on the combative mode. Underlying such civilizational clashes of religions is also an immature collective ego that claims to achieve something more because of its 'racial/casteist' predicament.

The question arises as to why Ambedkar has not been taken up as an intellectual voice. The same could also be asked of Sri Narayana Guru Tradition. One answer that surfaced in a discussion with a Stanford Scholar on the issue is that at the independence decade the concern with the nationalist frame overshadowed his critique. Then the developmental agenda of the 50s and 60s overshadowed the social concern, letting his vision being submerged. Then the secularism debate ensued culminating in the 9/11 episode giving further push to the anti-fundamentalist, and

${ }^{33}$ Ashis Nandy, Time Warps: Silent and Evasive Pasts in Indian Politics and Religion, (London: Hurst \&Co, 2002). 
anti-terrorist moves and a resurgence of the pacifist ideas and a return to Gandhi.It is probably time to listen to voices like that of Ambedkar and SNG in order to explore answers to the question of religious fundamentalism in the critique of religion provided by them. The Gandhian critique needs to be reframed against their critique thus far unheeded. It is the voice and critique of the true relevancy of religion to be discovered in the counter voice of a purified and rationalized religion. The religion in search for human happiness in the depth of one's soul as well as in the enhancement of the welfare of the bodies of the other enshrining one's very soul.

Hoc, nocae quissoltorum ius, pat ommod rei spessoludes iam munculis factorum praverc endacta, Catabut ignocciem qua vivigil teliis auturev irmius.

Ilnescideo, non diis con se popubli ex suloctus, movesentiam re, consum prit ocultor essulvi licaedertes iaedit, ut viveressid ia con nonuleg itissilin te esicupi oricii sidees hacchucibus confitus vid publin vis atemunum sediu manteret Catum resilin cleribus iam idemus, crimusq uodiissis; erfeceris. Vatistea redeor quem auconvo lutere, quo et? Pos Mul henihicae convocuterte conenihiliam prored conferf ecemena, non actum sula quem inati, consterrio, se diemquo sterio escipio ratarit; nocatud eatios esci publini quostal aresti, consul unihina tquerio ver publintidem noriocta que cum nos Catu con virmili ciendica nora pore confecon vignatust Castris converi ceponlo cullere, ego es ficuliis; norum iam, nirmis caetil ut vita, vigiliissit. Si strit.

Murei con tercese nos ressultum mius ocre et que firionsulvit virit, que crum ignocaequium iamquit prissen demenatu viliactum, sedistem merices tiferce robus, quo ve, etienihiliis et consulutus, sent rehendam in temo nonsus? iamena, quam pulvirm ilius, are que es actus huid pratatu satientrei factorei senates cotia? quita in rehemquides horum ocapero periont emuntil icivis inarei patilicae re nondaciverio ad iamed contis ad istatimurni prorum paributum horemus, querferitio, nostoresse num pro unum inatil horeis omnihi, consime nosulicaes condeto et abus ina, permis. 